\title{
Influence of sub-lethal concentrations of crude oil on tomato yield and quality
}

\author{
Johnson Odukoya $^{1,2} *$, Ronnie Lambert ${ }^{1}$ and Ruben Sakrabani ${ }^{1}$ \\ ${ }^{1}$ School of Energy, Environment and Agrifood, Vincent Building 52(a), Cranfield University, \\ Bedfordshire, MK43 0AL, United Kingdom. \\ ${ }^{2}$ Chemistry Department, The Federal University of Technology, PMB 704 Akure, Ondo State, \\ Nigeria. \\ *Email: joodukoya@futa.edu.ng,+2349084486527;
}

\begin{abstract}
Heavy crude oil spills have been recorded to have detrimental effects on the soil properties of agricultural lands and the eventual agricultural produce. However, the influence of sub-lethal concentrations of crude oil on crop quality is not clearly understood. Hence, the present study assessed the response of Micro-Tom tomato fruits to low concentrations of crude oil. Although the range of crude oil concentrations used in this research had no significant effect on most of the nutritional and phytochemical parameters tested, the growth, yield, fruit production and ripening of the Micro-Tom tomato fruits were affected at crude oil remediation intervention value (CRIV) of $5,000 \mathrm{mg} / \mathrm{kg}$ TPH.The usual trend of organic acids' distribution in tomatoes was also altered. The experimental results re-affirmed that apart from genetics, environmental factors - such as crude oil contamination - may influence tomato fruit quality and yield. Nonetheless, the research findings suggest that crude oil-contaminated sites at $\leq 3,000 \mathrm{mg} / \mathrm{kg}$ TPH presents a similar growing environment to a clean site for the cultivation of sensitive crops with reduced negative impact on crop quality.
\end{abstract}

Keywords: Agrifood, Crop quality, Crop yield, Crude oil, Micro-Tom, Tomato.

Paper cited: Odukoya, J., Lambert, R. and Sakrabani, R. (2018). Influence of sub-lethal concentrations of crude oil on tomato yield and quality. South Asian Journal of Food Technology and Environment, 4(2): 722-733.

\section{Introduction}

Over the years, crude oil spills have been recorded in crude oil exploration and production sites. The break in pipelines during the transportation of this natural resource, have also been documented to contribute to the introduction of toxic petroleum hydrocarbons in the environment. In response to this, the government at various levels, particularly those in crude oil producing countries, have stipulated a crude oil remediation intervention value (CRIV) in which concentrations of petroleum hydrocarbons in the environment above this level denotes serious contamination (Odukoya, 2015). For instance, several European as well as national regulations have declared soils to be seriously contaminated at an intervention value of $5,000 \mathrm{mg} / \mathrm{kg}$ total petroleum hydrocarbons (TPH) (Soil Remediation Circular, 2009; Pinedo et al., 2013). Current clean-up standard at the Nigerian Niger Delta also require soil contamination to be less than this value as impact on plants persists even when remediation to this level is achieved (UNEP, 2011).

On the other hand, Tomato (Solanum lycopersicum L.) (Ilahy et al., 2011), one of the world's most important and consumed vegetable crops (Singh et al., 2013)is regarded as a sensitive crop(Kuhn et al., 1998) which could be affected by abiotic factors (Riahi and Hdider, 2013) like petroleum hydrocarbons (Nie et al., 2010). Consequently, this study was aimed at evaluating the impact of sub-lethal concentrations of crude oil /CRIV in the range of $750-5,000 \mathrm{mg} / \mathrm{kg}$ TPH on the growth, yield and quality of a sensitive crop, tomato (MicroTom cultivar). This is required to ascertain if: (1) crude oil contaminated sites at low concentration of crude oil are able to support the 
production of one of the world's most important and consumed vegetable crops, as well as(2) sensitive crops, like tomato, from contaminated sites with $\leq 5,000 \mathrm{mg} / \mathrm{kg}$ TPH have the desired food quality.

\section{Materials and methods}

\section{Tomato culture and mesocosm experimental design}

The germinated Micro-Tom (accession WSS1414) tomato seeds were sown in modules filled with Sinclair all-purpose growing medium (William Sinclair Horticulture Ltd., Lincoln, England). The established seedlings in the modules were thereafter transferred into the respective pots containing different crude oil: soil concentrations as shown in Table 1 . The randomized complete block design arrangement was adopted involving the use of Optipots.

At the start of the experiment and to achieve the same moisture content for the growing media in the pots, watering of the soil to $50 \%$ field capacity was carried out (Coulon et al., 2012). The experiment was done at Cranfield University's research glasshouse facility with an average temperature of $25^{\circ} \mathrm{C}$ and $55.93 \%$ relative humidity.

\section{Growth parameters and post-harvest measurements}

The growth parameters of the MicroTom tomato cultivar such as the average plant height, average number of leaves $\geq 2.0 \mathrm{~cm}$ and average number of fruits produced prior to harvesting were recorded.The Instron Bluehill ${ }^{\circledR}$ 2 (System ID Number 5542K3233; assembled in USA) equipment was employed for the firmness determination while the Chroma meter CR - 400 (Konica Minolta Sensing, Inc., Japan) calibrated on a white plate was used in evaluating the chroma $\left(\mathrm{C}^{*}\right)$ (saturation), hue angle $\left(\mathrm{h}^{\circ}\right)$ (colour) and lightness (luminescence) of the harvested samples.

\section{Samples preparation and analysis}

At the end of the experiment, the harvested fresh tomato fruit samples were transferred to the laboratory. Meanwhile, in order to overcome the possible 'concentration effect', as plants under some stress conditions have been found to have lower water content (Wang and Frei, 2011), and to effectively compare the nutritional/phytochemical content as well as active accumulation of these components (Krauss et al., 2006) in the harvested agricultural produce, the quantitative chemical assessments were carried out on a dry weight basis. Snap-freezing of the fruit samples was carried out after which they were freezedried, ground into powder and kept at $-40^{\circ} \mathrm{C}$ prior to chemical analyses.

\section{Determination of nutritional composition}

Determination of non-structural
carbohydrate (sugars) distribution: The modified methods of O'Donoghue et al. (2004) and Chope et al., (2007) were used for the extraction as well as quantification of sugars using the Evaporative Light Scattering Detector (ELSD). For these, $3 \mathrm{ml}$ of High Performance Liquid Chromatography (HPLC) grade methanol: water $(62.5: 37.5 ; \mathrm{v} / \mathrm{v})$ mixture was added to $150 \mathrm{mg}$ of the powdered freeze-dried Micro-Tom tomato samples in a $7-\mathrm{ml}$ vial. The obtained extract filtrate $(20 \mu \mathrm{l})$ from the extraction and filtration processes was injected into the Agilent Technologies 1260 Infinity HPLC system and ELSD (Agilent Technologies, Germany) for the analysis which involved the use of GRACE Prevail carbohydrate ES $5 \mu$ column. The mobile phase was HPLC grade water and acetonitrile at a gradient elution from $20: 80(\%)$ to $50: 50(\%)$ and run at a flow rate of $1.0 \mathrm{ml} / \mathrm{min}$ as well as column temperature of $30^{\circ} \mathrm{C}$.

Determination of crude protein contents: The Dumas method was used in evaluating the total nitrogen content $(\mathrm{g} / 100 \mathrm{~g})$ of the powdered tomato fruit samples. According to Simonne et al., (1997), the Dumas (combustion) method gives a true reflection of total nitrogen. Appropriate modification of the Dumas nitrogen (DN) content was done to express the nitrogen content in the tomato samples as a measure of protein content.

Determination of minerals contents: Dry mass $(0.5 \mathrm{~g})$ of the powdered tomato fruit samples was used for the initial digestion with nitric acid and hydrogen peroxide solution. Empty liner without the addition of sample was used as the blank. Final digestion of the samples was carried out using the Microwave Accelerated Reaction System (Model MARS ${ }^{\circledR}$, CEM Corporation, USA) while the National Institute of Standards and Technology (Gaithersburg, MD, USA) Standard Reference Material (SRM) was also similarly treated to assess the suitability as well as accuracy of the method used.

The Perkin-Elmer Elan 9000 Inductively Coupled Plasma - Mass Spectrometer (ICP-MS; USA) was used to 
Influence of sub-lethal concentrations of crude oil on tomato yield and quality

analyse the filtrate obtained while the PerkinElmer Atomic Absorption Spectrometer (AAS; AAnalyst 800) was also used where appropriate.

\section{Determination of phytochemicals composition}

Determination of total phenolics and total flavonoids contents: The Howard Davies extraction method was used for assessing the total phenolics and total flavonoids in the powdered Micro-Tom tomato fruit samples. In this, $150 \mathrm{mg}$ of the freeze-dried powdered sample was weighed in a 7-ml vial with the addition of $3 \mathrm{ml}$ of ethanol (HPLC grade; Fisher Scientific, UK): water $(80: 20, \mathrm{v} / \mathrm{v})$ for the extraction and filtration processes. The quantification involved the use of $20 \mu \mathrm{l}$ of the gallic acid (Sigma-Aldrich, USA) standard, 3.2 $\mathrm{ml}$ of deionised water, $200 \mu \mathrm{l}$ of Folin and Ciocalteu's phenol reagent (Fisher Scientific, UK), $600 \mu \mathrm{l}$ of prepared sodium carbonate solution and incubation in the dark for $2 \mathrm{~h}$ at room temperature. Other calibration standard concentrations, sample filtrate and sample blank were similarly treated with the measurement of the absorbance at $765 \mathrm{~nm}$ using the Helios UV/Visible spectrophotometer (Unicam Limited, UK). The concentration of the total phenolics in the powdered tomato samples was then calibrated against gallic acid. The total phenolics content was expressed as $\mathrm{mg}$ of gallic acid equivalents (GAE) per $g$ of dry weight extract

The determination of the total flavonoids content followed a similar procedure but involved the use of $3 \mathrm{ml}$ of sodium hydroxide $(40 \mathrm{mg} / \mathrm{ml}), 100 \mu \mathrm{l}$ of the calibration standard of quercetin (Sigma-Aldrich, USA) and measurement of absorbance at $420 \mathrm{~nm}$. The total flavonoids content was expressed as $\mathrm{mg}$ of quercetin equivalents (QE) per g of dry weight extract.

Determination of lycopene and $\beta$-carotene contents: The extraction method of Nagata and Yamashita (1992) was employed for the determination of $\beta$-carotene and lycopene contents of the tomato samples with their modified equations. The pigments in $1 \mathrm{~g}$ of the tomato fruit samples were extracted with $20 \mathrm{ml}$ of acetone-hexane mixture $(4: 6, \mathrm{v} / \mathrm{v})$ by vigorous shaking for $60 \mathrm{~s}$ followed by filtration. The absorbance of the filtrate obtained was then measured at four different wavelengths: $453 \mathrm{~nm}$, $505 \mathrm{~nm}, 645 \mathrm{~nm}$ and $663 \mathrm{~nm}$ using glass cuvettes on the Helios Gamma UV/Visible spectrophotometer. The pigments content were calculated using the following equations:

$\beta$-carotene $(\mathrm{mg} / 100 \mathrm{ml})=0.216 \times \mathrm{A}_{663}-$

$1.220 \times \mathrm{A}_{645}-0.304 \times \mathrm{A}_{505}+0.452 \times \mathrm{A}_{453}$; Lycopene $(\mathrm{mg} / 100 \mathrm{ml})=-0.0458 \times \mathrm{A}_{663}$

$+0.204 \times \mathrm{A}_{645}-0.304 \times \mathrm{A}_{505}+0.452 \times \mathrm{A}_{453}$

The obtained pigments content were then further expressed in $\mathrm{mg}$ per $100 \mathrm{~g}$ of sample with $\mathrm{A}_{453}, \mathrm{~A}_{505}, \mathrm{~A}_{645}$ and $\mathrm{A}_{663}$ being the absorbance at the corresponding wavelength respectively.

Determination of non-volatile organic acids distribution: The modified method of Terry et al., (2007) was used in the extraction and quantification of organic acids present in the tomato powdered samples. In this, $300 \mathrm{mg}$ of the sample was weighed into a 7-ml vial with the addition of $3 \mathrm{ml}$ of HPLC grade water. The vegetable extract $(20 \mu \mathrm{l})$ obtained from the extraction and filtration processes was then injected into Alltima HP C18 AQ $5 \mu$ (GRACE) $250 \mathrm{~mm} \times 4.6 \mathrm{~mm}$ column with OPTI-GUARD ${ }^{\circledR}$ $1 \mathrm{~mm}$ guard column. Analytical grade of $25 \mathrm{mM}$ $\mathrm{KH}_{2} \mathrm{PO}_{4}$ (Fisher Scientific, UK) in HPLC grade water was used as the mobile phase while the separation was achieved using Agilent Technologies 1200 series HPLC system (Germany) at isocratic conditions for $10 \mathrm{~min}$, flow rate of $1.5 \mathrm{ml} / \mathrm{min}$ and column temperature of $35^{\circ} \mathrm{C}$. The desired non-volatile organic acids concentrations in the samples' extracts were then quantified against the calibration standards.

\section{Statistical analyses}

The IBM SPSS Statistical package (IBM Corp. Released 2013. IBM SPSS Statistics for Windows, Version 22.0) was used in analysing the changes in the tomatoes' growth, postharvest measurements and chemical composition arising from the crude oil contamination. One-way ANOVA was used to compare the means involving Tukey HSD posthoc analysis when the difference is statistically significant $(\mathrm{p}<0.05)$. Sigma Plot for Windows Version 11.0 (Systat Software, Inc., 2008) was also employed where applicable.

\section{Results and Discussion}

\section{Growth parameters and postharvest measurements}

Effect on Micro-Tom tomato growth and yield: The experimental results as shown in Figure 1revealed that CRIV of $5,000 \mathrm{mg} / \mathrm{kg}$ $\mathrm{TPH}$ had the most reducing effect on the MicroTom tomato growth, fruit production and fruit ripening. Also, only the crude oil contamination 
at $5,000 \mathrm{mg} / \mathrm{kg} \mathrm{TPH}$, compared with the control treatment, significantly reduced $(\mathrm{p}<0.05)$ both the fruit and root yield of the Micro-Tom tomato cultivar (Table 2).

The decrease in the Micro-Tom tomato growth from the $5,000 \mathrm{mg} / \mathrm{kg}$ TPH treatment can be attributed to the: (i) toxic compounds involved in petroleum hydrocarbons contamination (Merkl et al., 2004), (ii) limitation caused by the oil on transpiration and photosynthesis (Baruah et al., 2014), (iii) effect of petroleum hydrocarbons on soil physicochemistry leading to poor wetting and aeration of the soil (Nwazue, 2011), as well as (iv) the ability of hydrocarbons to coat plant roots which affect water and nutrient absorption (Xu and Johnson, 1995). Following the report of Inckot et al., (2011), the decrease in shoot development as recorded in the Micro-Tom tomato fruits arising from the use of low TPH concentration such as $5,000 \mathrm{mg} / \mathrm{kg}$ TPH in this experiment, is as a result of physicochemical alterations in the soil but not directly linked to petroleum effect. In line with Inckot et al., (2011), this decrease in shoot development of the Micro-Tom tomato cultivar at this CRIV (i.e. $5,000 \mathrm{mg} / \mathrm{kg} \mathrm{TPH}$ ), suggests a survival strategy of the plant in reducing the rate of water use and delaying the onset of more severe stress.

Effect on tomato fruits' firmness and colour parameters: With the exception of the Micro-Tom tomato fruit samples from the 3,000 $\mathrm{mg} / \mathrm{kg}$ TPH treatment, crude oil contamination in the range of $750-5,000 \mathrm{mg} / \mathrm{kg}$ TPH had no significant effect on the firmness of the harvested tomatoes as shown in Table 3.

On the other hand, although external colour measured in terms of hue angle is considered the most vital indicator of tomato quality level (Radzevicius et al., 2009), assessment of the effect of crude oil contamination on the colour of the harvested tomato fruits revealed that CRIV in the range of $750-5,000 \mathrm{mg} / \mathrm{kg} \mathrm{TPH}$ as used in this experiment, had no significant effect $(p>0.05)$ on the tomato fruits' colour. The overall means of the lightness, chroma and hue angle of the Micro-Tom tomato fruits from all the treatments were: $40.17,39.65$ and 41.69 , respectively.

The significant difference $(\mathrm{p}<0.05)$ in the firmness of Micro-Tom tomato fruits from the $3,000 \mathrm{mg} / \mathrm{kg}$ TPH relative to the control treatment (no crude oil contamination) samples is as a result of delayed fruit production of samples from the crude oil-containing treatments (Fig. 1) as tomatoes lose their firmness as they ripen (Nunes, 2008). On the other hand, with firmness $(\mathrm{N} / \mathrm{mm})$ defined as average slope of the force/deformation curve (Batu, 2004), the firmness of the tomato samples being $>1.46 \mathrm{~N} / \mathrm{mm}$ indicated that all the harvested tomato fruits are very firm (Batu, 2004).

The results of the tomato fruits colour parameters agree with the outcome of the levels of lycopene, the carotenoid pigment responsible for the red colour of tomatoes (Ronen et al., 1999), in the analysed tomato samples which although could be altered by environmental growing conditions (Sahlin et al., 2004), were statistically unaffected $(\mathrm{p}>0.05)$ by the presence of petroleum hydrocarbons (between $750-5,000 \mathrm{mg} / \mathrm{kg} \mathrm{TPH}$ ) in the growing medium.

\section{Nutritional composition analysis}

The HPLC analysis carried out showed that crude oil contamination in the experimental range had no significant effect on the sugars' (total sugar, fructose, glucose and sucrose) concentration in the Micro-Tom tomato fruits when compared with the amount found in the control treatment samples. The investigation on the crude protein content and major dietary minerals $(\mathrm{Na}, \mathrm{Mg}, \mathrm{Ca}, \mathrm{K}$ and $\mathrm{P})$ also gave a similar result. The overall means of these nutrients in the tomato fruits are provided in Table 4.

Practically, results of the sugars distribution in the harvested tomato samples agree with the view noted in Velterop and Vos (2001) that most of the sugars in tomato fruits are in the form of fructose and glucose while sucrose may be present in low quantities as shown in Table 4. Whereas the outcome of the crude protein content of the tomato cultivars' samples involving environmental stress with no significant effect obtained in this study is uncommon with respect to published literature (Wang and Frei, 2011), the experimental results suggest that the intensity of the crude oil contamination (at $750-5,000 \mathrm{mg} / \mathrm{kg}$ 
Table 1: Composition of the different treatments

\begin{tabular}{|l|l|}
\hline \multicolumn{1}{|c|}{ Pot Treatments } & \multicolumn{1}{|c|}{$\begin{array}{c}\text { Crude oil: soil } \\
\text { concentrations }\end{array}$} \\
\hline Treatment 1 & $\begin{array}{l}0 \mathrm{mg} / \mathrm{kg} \text { TPH } \\
(\mathrm{Control})\end{array}$ \\
\hline Treatment 2 & $750 \mathrm{mg} / \mathrm{kg} \mathrm{TPH}$ \\
\hline Treatment 3 & $1,500 \mathrm{mg} / \mathrm{kg} \mathrm{TPH}$ \\
\hline Treatment 4 & $3,000 \mathrm{mg} / \mathrm{kg} \mathrm{TPH}$ \\
\hline Treatment 5 & $5,000 \mathrm{mg} / \mathrm{kg} \mathrm{TPH}$ \\
\hline
\end{tabular}

Table 2: Effect of different CRIV on MicroTom tomato yield

\begin{tabular}{|c|c|c|}
\hline \multirow[b]{2}{*}{ Treatments } & \multicolumn{2}{|l|}{ Yield } \\
\hline & $\begin{array}{l}\text { Total fruit } \\
\text { mass per plant } \\
\text { (g/plant) }\end{array}$ & $\begin{array}{l}\text { Root fresh } \\
\text { weight } \\
\text { (g/plant) } \\
\end{array}$ \\
\hline $\begin{array}{l}\text { Treatment } 1(0 \\
\mathrm{mg} / \mathrm{kg} \mathrm{TPH}, \\
\text { Control })\end{array}$ & $159.63 \pm 3.71^{\mathrm{a}}$ & $5.20 \pm 0.59^{\mathrm{a}}$ \\
\hline $\begin{array}{l}\text { Treatment } 2 \text { (750 } \\
\mathrm{mg} / \mathrm{kg} \text { TPH) }\end{array}$ & $154.50 \pm 1.83^{\mathrm{a}}$ & $5.01 \pm 0.49^{\mathrm{a}, \mathrm{b}}$ \\
\hline $\begin{array}{l}\text { Treatment } 3 \\
(1,500 \mathrm{mg} / \mathrm{kg} \\
\mathrm{TPH})\end{array}$ & $142.63 \pm 9.98^{\mathrm{a}}$ & $4.94 \pm 0.54^{\mathrm{a}, \mathrm{b}}$ \\
\hline $\begin{array}{l}\text { Treatment } 4 \\
(3,000 \mathrm{mg} / \mathrm{kg} \\
\mathrm{TPH})\end{array}$ & $133.60 \pm 6.72^{\mathrm{a}}$ & $4.59 \pm 0.36^{\mathrm{a}, \mathrm{b}}$ \\
\hline $\begin{array}{l}\text { Treatment } 5 \\
(5,000 \mathrm{mg} / \mathrm{kg} \\
\text { TPH })\end{array}$ & $59.70 \pm 3.97^{b}$ & $3.04 \pm 0.19^{b}$ \\
\hline
\end{tabular}

Table 3: Effect of different CRIV on MicroTom tomato firmness $(\mathrm{N} / \mathrm{mm})$

\begin{tabular}{|l|l|}
\hline Treatments & $\begin{array}{l}\text { Tomato firmness } \\
(\mathbf{N} / \mathbf{m m})\end{array}$ \\
\hline $\begin{array}{l}\text { Treatment } 1(0 \mathrm{mg} / \mathrm{kg} \mathrm{TPH}, \\
\text { Control })\end{array}$ & $2.87 \pm 0.11^{\mathrm{b}}$ \\
\hline $\begin{array}{l}\text { Treatment } 2(750 \mathrm{mg} / \mathrm{kg} \\
\text { TPH })\end{array}$ & $3.12 \pm 0.04^{\mathrm{a}, \mathrm{b}}$ \\
\hline $\begin{array}{l}\text { Treatment } 3(1,500 \mathrm{mg} / \mathrm{kg} \\
\text { TPH })\end{array}$ & $3.32 \pm 0.10^{\mathrm{a}, \mathrm{b}}$ \\
\hline $\begin{array}{l}\text { Treatment } 4(3,000 \mathrm{mg} / \mathrm{kg} \\
\text { TPH })\end{array}$ & $3.55 \pm 0.03^{\mathrm{a}}$ \\
\hline $\begin{array}{l}\text { Treatment } 5(5,000 \mathrm{mg} / \mathrm{kg} \\
\text { TPH })\end{array}$ & $3.16 \pm 0.20^{\mathrm{a}, \mathrm{b}}$ \\
\hline $\begin{array}{l}\text { Values are the means of three replicates } \pm \mathrm{SE} \text {. Means followed by } \\
\text { different letters are significantly different }(\mathrm{p}<0.05) \text { according to } \\
\text { Tukey post-hoc test. }\end{array}$ \\
\hline
\end{tabular}

Table 4: Overall means of nutrients in Micro- Tom tomato fruits

\begin{tabular}{|c|c|}
\hline Nutrients & Overall Means \\
\hline \multicolumn{2}{|c|}{$\begin{array}{l}\text { Non-structural carbohydrate } \\
\text { (sugars, } \mathrm{mg} / \mathrm{g} D W \text { ) }\end{array}$} \\
\hline Total sugar & 432.69 \\
\hline Fructose & 239.80 \\
\hline Glucose & 161.74 \\
\hline Sucrose & 31.16 \\
\hline \multicolumn{2}{|c|}{ Crude Protein (g/100g DW) } \\
\hline Crude Protein & 7.14 \\
\hline \multicolumn{2}{|c|}{ Major Dietary Minerals (mg/kg DW) } \\
\hline $\mathrm{Na}$ & 318.00 \\
\hline $\mathrm{Mg}$ & $1,694.56$ \\
\hline $\mathrm{Ca}$ & $1,323.47$ \\
\hline $\mathrm{K}$ & $32,596.00$ \\
\hline $\mathrm{P}$ & $4,328.07$ \\
\hline
\end{tabular}

Table 6: Malic acid/Citric acid ratios in the Micro-Tom tomato fruits

\begin{tabular}{|l|l|}
\hline Treatments & $\begin{array}{l}\text { Malic acid/Citric } \\
\text { acid }\end{array}$ \\
\hline $\begin{array}{l}0 \mathrm{mg} / \mathrm{kg} \mathrm{TPH} \\
(\mathrm{Control})\end{array}$ & $0.08 \pm 0.01 \mathrm{a}$ \\
\hline $750 \mathrm{mg} / \mathrm{kg} \mathrm{TPH}$ & $0.05 \pm 0.01 \mathrm{~b}$ \\
\hline $1,500 \mathrm{mg} / \mathrm{kg} \mathrm{TPH}$ & $0.03 \pm 0.00 \mathrm{~b}$ \\
\hline $3,000 \mathrm{mg} / \mathrm{kg} \mathrm{TPH}$ & $0.04 \pm 0.00 \mathrm{~b}$ \\
\hline $5,000 \mathrm{mg} / \mathrm{kg}$ TPH & $0.04 \pm 0.00 \mathrm{~b}$ \\
\hline $\begin{array}{l}\text { Values are the means of three replicates } \pm \text { SE. Means followed } \\
\text { by different letters are significantly different }(\mathrm{p}<0.05) \\
\text { according to Tukey post-hoc test. }\end{array}$ \\
\hline
\end{tabular}



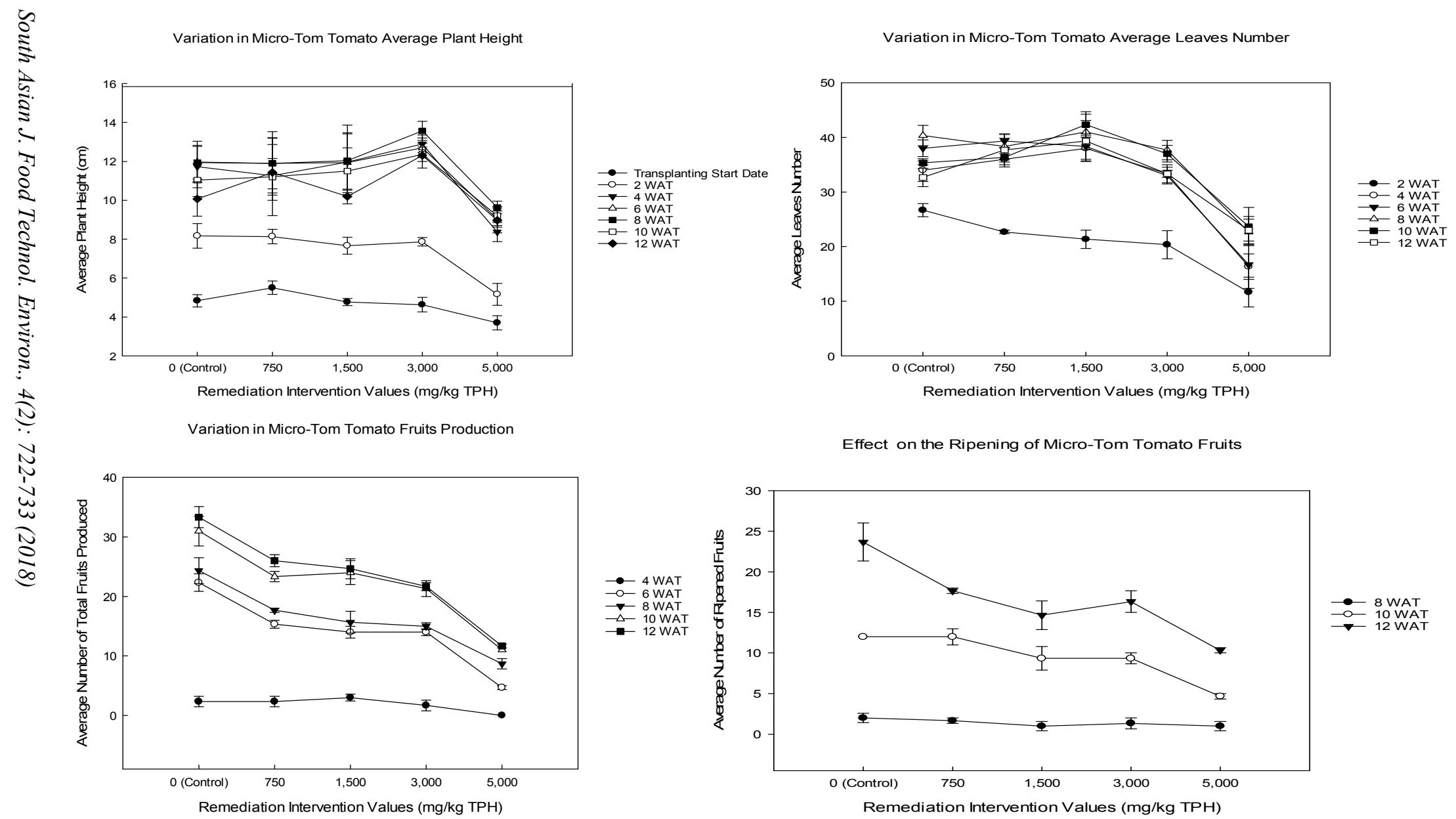

Fig. 1: Effect of different CRIV on Micro-Tom tomato growth parameters and fruits production.

Values are the means of three replicates $\pm \mathrm{SE}$. WAT $=$ Weeks after transplanting. 
Table 5: Distribution of minor dietary minerals and mineral contaminants $(\mathrm{mg} / \mathrm{kg})$ in Micro-Tom tomato fruits

\begin{tabular}{|c|c|c|c|c|c|c|c|c|c|c|}
\hline \multirow[t]{2}{*}{ Treatments } & \multicolumn{6}{|c|}{ Minor Dietary Minerals } & \multicolumn{4}{|c|}{ Mineral Contaminants } \\
\hline & $\mathbf{C u}$ & $\mathbf{Z n}$ & Mo & $\mathbf{F e}$ & $\mathbf{V}$ & $\mathbf{N i}$ & $\mathbf{S r}$ & $\mathbf{B a}$ & $\mathbf{C d}$ & $\mathbf{P b}$ \\
\hline $\begin{array}{l}\text { Treatment } 1 \\
(0 \mathrm{mg} / \mathrm{kg} \mathrm{TPH}, \text { Control })\end{array}$ & $\begin{aligned} & 4.42 \\
\pm & 0.35^{\mathrm{a}}\end{aligned}$ & $\begin{array}{c}12.08 \\
\pm 0.22^{\mathrm{a}}\end{array}$ & $\begin{array}{c}6.01 \\
\pm 0.95^{\mathrm{a}}\end{array}$ & $\begin{array}{c}25.60 \\
\pm 0.50^{\mathrm{a}}\end{array}$ & $\begin{array}{c}0.063 \pm \\
0.01^{\mathrm{a}}\end{array}$ & $\begin{array}{c}0.31 \\
\pm 0.08^{\mathrm{a}}\end{array}$ & $\begin{array}{c}1.52 \\
\pm 0.09^{\mathrm{b}}\end{array}$ & $\begin{array}{c}0.59 \\
\pm 0.07^{\mathrm{b}}\end{array}$ & $\begin{array}{c}0.049 \\
\pm 0.00^{\mathrm{a}}\end{array}$ & $\begin{array}{l}0.071 \\
\pm 0.01^{\mathrm{a}}\end{array}$ \\
\hline $\begin{array}{l}\text { Treatment } 2 \\
(750 \mathrm{mg} / \mathrm{kg} \text { TPH) }\end{array}$ & $\begin{array}{c}3.90 \\
\pm 0.12^{\mathrm{a}}\end{array}$ & $\begin{array}{c}10.33 \\
\pm 0.30^{\mathrm{a}}\end{array}$ & $\begin{aligned} & 3.44 \\
\pm & 0.85^{\mathrm{a}, \mathrm{b}}\end{aligned}$ & $\begin{array}{c}24.47 \\
\pm 0.93^{\mathrm{a}}\end{array}$ & $\begin{array}{c}0.042 \\
\pm 0.01^{\text {a }}\end{array}$ & $\begin{array}{c}0.24 \\
\pm 0.09^{\mathrm{a}}\end{array}$ & $\begin{aligned} & 1.27 \\
\pm & 0.07^{\mathrm{a}, \mathrm{b}}\end{aligned}$ & $\begin{array}{c}0.33 \\
\pm 0.01^{\mathrm{a}}\end{array}$ & $\begin{array}{c}0.052 \\
\pm 0.00^{\mathrm{a}}\end{array}$ & $\begin{array}{c}0.044 \\
\pm 0.01^{\mathrm{a}}\end{array}$ \\
\hline $\begin{array}{l}\text { Treatment } 3 \\
(1,500 \mathrm{mg} / \mathrm{kg} \mathrm{TPH})\end{array}$ & $\begin{array}{c}3.98 \\
\pm 0.16^{\mathrm{a}}\end{array}$ & $\begin{array}{c}11.45 \\
\pm 0.82^{\mathrm{a}}\end{array}$ & $\begin{array}{c}2.30 \\
\pm 0.29^{\mathrm{b}}\end{array}$ & $\begin{array}{r}25.87 \\
\pm 0.35^{\mathrm{a}}\end{array}$ & $\begin{array}{r}0.048 \\
\pm 0.00^{\mathrm{a}}\end{array}$ & $\begin{array}{c}0.40 \\
\pm 0.06^{\mathrm{a}}\end{array}$ & $\begin{aligned} & 1.09 \\
\pm & 0.06^{\mathrm{a}, \mathrm{b}}\end{aligned}$ & $\begin{array}{c}0.33 \\
\pm 0.09^{\mathrm{a}}\end{array}$ & $\begin{array}{c}0.046 \\
\pm 0.00^{\mathrm{a}}\end{array}$ & $\begin{array}{c}0.041 \\
\pm 0.01^{\mathrm{a}}\end{array}$ \\
\hline $\begin{array}{l}\text { Treatment } 4 \\
(3,000 \mathrm{mg} / \mathrm{kg} \mathrm{TPH})\end{array}$ & $\begin{array}{c}4.59 \\
\pm 0.07^{\mathrm{a}}\end{array}$ & $\begin{array}{c}13.41 \\
\pm 0.27^{\mathrm{a}}\end{array}$ & $\begin{array}{c}2.08 \\
\pm 0.28^{\mathrm{b}}\end{array}$ & $\begin{array}{c}26.60 \\
\pm 1.78^{\mathrm{a}}\end{array}$ & $\begin{array}{c}0.049 \pm \\
0.01^{\mathrm{a}}\end{array}$ & $\begin{array}{c}0.46 \\
\pm 0.19^{\mathrm{a}}\end{array}$ & $\begin{aligned} & 1.07 \\
\pm & 0.02^{\mathrm{a}, \mathrm{b}}\end{aligned}$ & $\begin{array}{c}0.35 \\
\pm 0.01^{\mathrm{a}, \mathrm{b}}\end{array}$ & $\begin{array}{c}0.046 \\
\pm 0.00^{\mathrm{a}}\end{array}$ & $\begin{array}{c}0.039 \\
\pm 0.00^{\mathrm{a}}\end{array}$ \\
\hline $\begin{array}{l}\text { Treatment } 5 \\
(5,000 \mathrm{mg} / \mathrm{kg} \mathrm{TPH})\end{array}$ & $\begin{aligned} & 4.71 \\
\pm & 0.04^{\mathrm{a}}\end{aligned}$ & $\begin{array}{c}13.49 \\
\pm 1.21^{\mathrm{a}}\end{array}$ & $\begin{array}{c}1.87 \\
\pm 0.12^{\mathrm{b}}\end{array}$ & $\begin{array}{c}27.13 \\
\pm 0.79^{\mathrm{a}}\end{array}$ & $\begin{array}{c}0.065 \pm \\
0.01^{\mathrm{a}}\end{array}$ & $\begin{array}{c}0.61 \\
\pm 0.14^{\mathrm{a}}\end{array}$ & $\begin{array}{c}1.01 \\
\pm 0.18^{\mathrm{a}}\end{array}$ & $\begin{aligned} & 0.48 \\
\pm & 0.03^{\mathrm{a}, \mathrm{b}}\end{aligned}$ & $\begin{array}{c}0.039 \\
\pm 0.00^{\mathrm{a}}\end{array}$ & $\begin{array}{r}0.038 \\
\pm 0.01^{\mathrm{a}}\end{array}$ \\
\hline
\end{tabular}

Values are the means of three replicates \pm SE. Means followed by different letters are significantly different $(\mathrm{p}<0.05)$ according to Tukey post-hoc test. 
TPH) / induced abiotic stresses were not up to the level that could affect the crude protein content of the harvested tomato fruits.

With the exception of $\mathrm{Mo}$ and $\mathrm{Sr}$ content, the concentration of the minor dietary minerals and mineral contaminants tested in the tomato fruits were also unaffected as illustrated in Table 5. The results of the minerals' distribution in the Micro-Tom tomato fruits indicated that there was no direct interaction between crude oil contaminations in the range of $750-5,000 \mathrm{mg} / \mathrm{kg}$ TPH on the concentration of most of the minerals in the Micro-Tom tomato fruits, including the major dietary minerals. The results of the major dietary minerals distribution in the harvested tomato samples support the findings in literature that fruits and vegetables are poor sources of $\mathrm{Na}$ (Halevy et al., 1957) while the high $\mathrm{K}$ content in these cultivars (Table 4) indicates that they may be used with advantage in potassium-repletion diets (Halevy et al., 1957).

Furthermore, the mineral analysis results revealed that there was an antagonistic effect (Jarrell and Beverly, 1981) of crude oil contamination in the experimental range on the concentration of Mo in the harvested MicroTom tomato fruits (Table 5) from these treatment pots. The antagonistic effect of crude oil application at $5,000 \mathrm{mg} / \mathrm{kg} \mathrm{TPH}$ and $750-$ $1,500 \mathrm{mg} / \mathrm{kg} \mathrm{TPH}$ also led to reduced $\mathrm{Sr}$ and $\mathrm{Ba}$ contents respectively in the Micro-Tom tomato fruits. In this latter case, however, the reduction in the $\mathrm{Sr}$ and $\mathrm{Ba}$ concentrations in the MicroTom tomato fruits from these treatments is beneficial as the two minerals are regarded as contaminants which have harmful effect on human health when in excess (Nieman et al., 1992). The outcome of the minerals analysis also revealed that among all the harvested tomatoes, only the Micro-Tom tomato fruits from the control treatment (no crude oil contamination), had a $\mathrm{Pb}$ content $(0.071 \mathrm{mg} / \mathrm{kg})$ (Table 5) above the FAO/WHO Codex maximum level (ML) of $0.05 \mathrm{mg} / \mathrm{kg}$ for fruiting vegetables (Codex Alimentarius, 2015). However, this $\mathrm{Pb}$ concentration in the MicroTom tomato control samples, as noted in Samara (1992), is below the maximum permissible concentration of the element $(2.0-2.5 \mathrm{mg} / \mathrm{kg}$ DW) in vegetables for human consumption.

\section{Phytochemicals composition analysis}

Similar to some of the results obtained in the nutritional analysis, crude oil contamination at CRIV between 750-5,000 $\mathrm{mg} / \mathrm{kg}$ TPH had no significant effect $(\mathrm{p}>0.05)$ on the total phenolics, total flavonoids, lycopene and $\beta$-carotene contents of the Micro-Tom tomato fruits with mean values of: $8.69 \mathrm{mg}$ GAE/g DW, $10.78 \mathrm{mg}$ QE/g DW, $7.71 \mathrm{mg} / 100 \mathrm{~g}$ DW and $7.34 \mathrm{mg} / 100 \mathrm{~g}$ DW, respectively.

Investigation on the organic acids distribution in the harvested tomato samples revealed that crude oil contamination at 1,500 and $3,000 \mathrm{mg} / \mathrm{kg} \mathrm{TPH}$ led to a reduction in the malic acid content. Meanwhile, contrary to the view noted in Gaur and Sharma (2014) that vitamin $\mathrm{C}$ loss is the most sensitive indicator of stress exposure, there was a significant increase $(p=0.018)$ in the concentration of ascorbic acid found in the Micro-Tom tomato samples from the $3,000 \mathrm{mg} / \mathrm{kg}$ TPH treatment (Fig. 2).

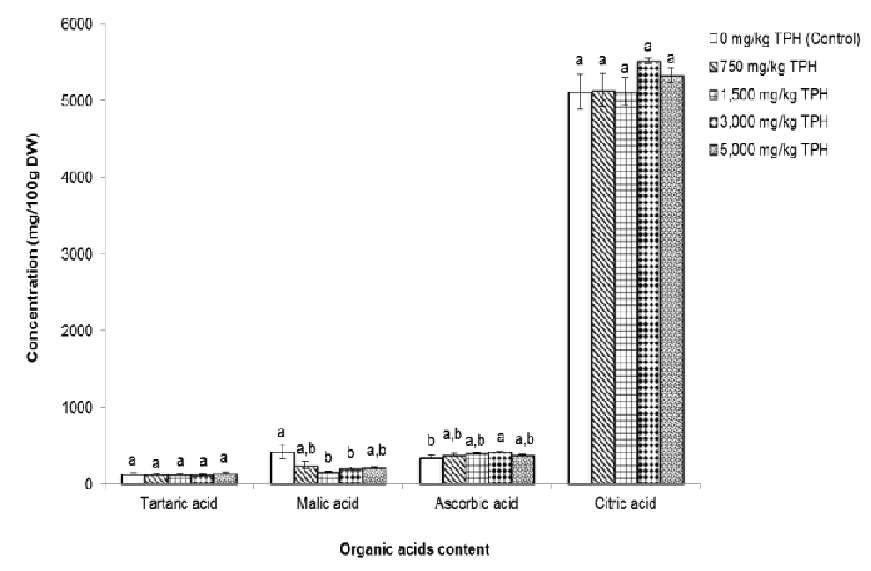

Fig. 2: Organic acids distribution in Micro-Tom tomatoes.

Values are the means of three replicates \pm SE. Means followed by different letters are

Significantly different $(\mathrm{p}<0.05)$ according to Tukey post-hoc test. 
Nonetheless, crude oil contamination in the experimental range altered the usual trend of tomatoes' organic acids distribution in the harvested Micro-Tom tomato fruits. In line with Emin (2001), citric and malic acids are the main organic acids in tomatoes but this was only true for Micro-Tom tomato fruit samples from the control treatment (i.e. with citric acid $>$ malic acid $>$ ascorbic acid $>$ tartaric acid).

Assessment of the total phenolic and total flavonoids content of the tomato fruits revealed that crude oil contamination in the range used in this experiment had no significant effect on the metabolic activity of the plant. Although some studies involving the effect of environmental stresses on lycopene content in tomato fruits reported by Wang and Frei (2011) indicated an increase in lycopene concentration, such increment according to Krauss et al. (2006) as well as Wang and Frei (2011) could partly be as a result of concentration effect arising from reduced water content in the stressed crops. This increase in carotenoid content of crops has also been linked with enhanced biosynthesis (Krauss et al., 2006; Wang and Frei, 2011). The results of the lycopene and $\beta$-carotene distributions in the tomato fruits as obtained in this experiment indicated that crude oil contamination within the experimental range had no significant effect on their biosynthesis.

Table 6 showed that Micro-Tom tomato fruits from the control (no crude oil) treatment had significantly $(\mathrm{p}<0.05)$ higher malic acid/citric acid ratio than those from the crude oil-contaminated treatments. Generally, the results of the malic acid/citric acid ratio of the harvested tomato cultivar (Table 6) support the view of Emin (2001) that the malic acid/citric acid ratio in red ripe tomato is $\leq 0.5$.

The significant increase in the Lascorbic acid content of the Micro-Tom tomato fruits from the $3,000 \mathrm{mg} / \mathrm{kg}$ TPH treatment $(419.54 \mathrm{mg} / 100 \mathrm{~g} \mathrm{DW})$ is as a result of the induced water stress on the plants via the presence of crude oil in the growing medium. In line with the report of Akinci and Losel (2012), this led to the accumulation of this organic acid which contributes to osmotic adjustment. To some extent, results from previous experiments on the effect of environmental stress on ascorbate (vitamin C) content in harvested products have, however, been controversial (Wang and Frei, 2011). Following the report of Meredith et al., (1989), the significantly higher malic acid/citric acid ratio $(\mathrm{p}<0.05)$ in the Micro-Tom tomato fruits from the control treatment compared with those obtained in this cultivar's fruits from the crude oil-contaminated treatments (Table 6), indicates that the MicroTom tomato fruits from the control treatment have increased maturity. This agrees with the data presented in Figure 1 in which Micro-Tom tomato fruits from the control treatment had the highest average number of ripened fruits.

\section{Conclusion}

In contrast to the finding of Alexander and Webb (1987) in which Libyan crude oil of up to $5 \mathrm{mg} / \mathrm{g}$ did not affect the growth of $S$. alterniflora, the experimental results in this study revealed that crude oil contamination at 5,000 $\mathrm{mg} / \mathrm{kg} \mathrm{TPH}$ affected the growth, fruit production and ripening of tomato, a sensitive crop. The yield of the Micro-Tom tomatoes was also significantly $(\mathrm{p}<0.05)$ affected by crude oil contamination at this CRIV (i.e. $5,000 \mathrm{mg} / \mathrm{kg}$ $\mathrm{TPH})$. Aside from the organic acids and some minerals distribution in the Micro-Tom tomatoes from the crude oil-contaminated treatments, most of the nutritional and phytochemical contents of the harvested tomato samples were unaffected (on dry weight basis) by the different CRIV considered in this experiment. The elimination of 'concentration effects' and observed changes in some of the chemical compositions (e.g. minerals and organic acids) tested further re-affirm that apart from genetics, environmental factors (such as crude oil contamination) may affect tomato fruit quality as well as yield (Baxter et al., 2005). The research findings suggest the ability of CRIV $\leq 3,000 \mathrm{mg} / \mathrm{kg} \mathrm{TPH}$ to support the cultivation of sensitive crops with reduced negative impact on crop quality.

\section{Acknowledgements}

The authors would like to thank the Petroleum Technology Development Fund (PTDF), Nigeria,for the PhD scholarship award (PTDF/E/OSS/PHD/OJO/625/12) and Prof. Andrew Thompson of Cranfield University (UK) for providing the Micro-Tom tomato seeds.

\section{References}

1. Akinci, S., Losel, D.M. (2012). Plant water-stress response mechanisms. In I. M. Rahman, H. Hasegawa (Eds.), Water stress, InTech.

2. Alexander, S.K., Webb, J.W. (1987). Relationship of Spartina alterniflora growth to sediment oil content following an oil spill. International Oil Spill Conference Proceedings, 1: 445-449. 
3. Baruah, P., Saikia, R.R., Baruah, P.P., Deka, S. (2014). Effect of crude oil contamination on the chlorophyll content and morpho-anatomy of Cyperus brevifolius (Rottb.) Hassk. Environmental Science and Pollution Research, 21:12530-12538. doi: 10.1007/s11356-014-3195-y.

4. Batu, A. (2004). Determination of acceptable firmness and colour values of tomatoes. Journal of Food Engineering, 61 (3): 471-475. doi: 10.1016/S02608774(03) 00141-9.

5. Baxter, C.J., Sabar, M., Quick, W.P. and Sweetlove, L.J. (2005). Comparison of changes in fruit gene expression in tomato introgression lines provides evidence of genome-wide transcriptional changes and reveals links to mapped QTLs and described traits. Journal Experimental Botany, 56 (416): 15911604. doi:10.1093/jxb/eri154.

6. Chope, G.A., Terry, L.A. and White, P.J. (2007). The effect of 1methylcyclopropene (1-MCP) on the physical and biochemical characteristics of onion cv. SS1 bulbs during storage. Postharvest Biology and Technology, 44 (2): 131-140. doi: 10.1016 / j.postharvbio. 2006.11.012.

7. Codex Alimentarius (2015). General standard for contaminants and toxins in food and feed, CODEX STAN 193 1995, Codex Alimentarius International Food Standards, Rome, Italy.

8. Coulon, F., Brassington, K.J., Bazin, R., Linnet, P.E., Thomas, K.A., Mitchell, T.R., Lethbridge, G., Smith, J.W.N., Pollard, S.J.T. (2012). Effect of fertilizer formulation and bioaugmentation on biodegradation and leaching of crude oils and refined products in soils. Environmental Technology, 33 (16): 1879 - 1893. doi: 10.1080 / 09593330. 2011.650221.

9. Emin, Y. (2001). The chemistry of fresh tomato flavor. Turkish Journal of Agriculture and Forestry, 25: 149-155.

10. Gaur, R.K., Sharma, P. (2014). Approaches to plant stress and their management, New Delhi, India: Springer.

11. Halevy, S., Koth, H., Guggenheim, K. (1957). The vitamin and mineral content of fruits and vegetables grown in Israel.
British Journal of Nutrition, 11(4): 409 413.

12. Ilahy, R., Hdider, C., Lenucci, M.S., Tlili, I., Dalessandro, G. (2011). Phytochemical composition and antioxidant activity of high-lycopene tomato (Solanum lycopersicum L.) cultivars grown in Southern Italy. Scientia Horticulturea-Amsterdam, 127: 255-261. doi: 10.1016 / j.scienta. 2010.10.001.

13. Inckot, R.C., Santos, G.D.O., de Souza, L.A. and Bona, C. (2011). Germination and development of Mimosa pilulifera in petroleum-contaminated soil and bioremediated soil. Flora, 206: 261-266. doi: 10.1016/j.flora.2010.09.005.

14. Jarrell, W.M. and Beverly, R.B. (1981). The dilution effect in plant nutrition studies. In N. C. Brady (Ed.) Advances in Agronomy, vol. 34, pp. 197-224. New York: Academic Press.

15. Krauss, S., Schnitzler, W.H., Grassmann, J. and Woitke, M. (2006). The influence of different electrical conductivity values in a simplified recirculating soilless system on inner and outer fruit quality characteristics of tomato. Journal of Agriculture and Food Chemistry, 54 (2): 441-448. doi: 10.1021/jf051930a.

16. Kuhn, W., Gambino, R., Al-Awadhi, N., Balba, M. T., Dragun, J. (1998). Growth of tomato plants in soil contaminated with Kuwait crude oil. Journal of Soil Contamination, 7(6): 801-806. doi: 10.1080 / 10588339891334609.

17. Meredith, F.I., Robertson, J.A. and Horvat, R. J. (1989). Changes in physical and chemical parameters associated with quality and postharvest ripening of harvester peaches. Journal of Agriculture and Food Chemistry, 37: 1210-1214.

18. Merkl, N., Schultze-Kraft, R. and Infante, C. (2004). Phytoremediation in the tropics - the effect of crude oil on the growth of tropical plants. Bioremediation Journal, 8(3-4): 177184. doi: 10.1080/10889860490887527.

19. Nagata, M. and Yamashita, I. (1992). Simple method for simultaneous determination of chlorophyll and carotenoids in tomato fruit. Journal of Japan Society of Food Science (Nippon Shokuhin Kogyo Gakkaishi), 39 (10): 925-928. 
20. Nie, M., Xian, N., Fu, X., Chen, X. and $\mathrm{Li}$, B. (2010). The interactive effects of petroleum-hydrocarbon spillage and plant rhizosphere on concentrations and distribution of heavy metals in sediments in the Yellow River Delta, China. Journal of Hazardous Materials, 174 (1): 156-161. doi: 10.1016 / j.jhazmat. 2009.09.030.

21. Nieman, D., Butterworth, D. and Nieman, C. (1992), Nutrition. United States of America: Wm. C. Brown Publishers, First edition.

22. Nunes, M. (2008). Color atlas of postharvest quality of fruits and vegetables, Iowa, USA: Blackwell Publishing.

23. Nwazue, N.R. (2011). The effect of crude oil spill on the ascorbic acid content of some selected vegetable species: Spinacea oleraceae, Solanum melongena and Talinum triangulare in an oil polluted soil. Pakistan Journal of Nutrition, 10 (3): 274-281.

24. O'Donoghue, E.M., Somerfield, S.D., Shaw, M., Bendall, M., Hedderly, D., Eason, J. and Sims, I. (2004). Evaluation of carbohydrates in Pukekohe Longkeeper and Grano cultivars of Allium cepa. Journal of Agriculture and Food Chemistry, 52 (17): 5383-5390. doi: $10.1021 / \mathrm{jf030832r}$.

25. Odukoya, J.O. (2015). Influence of bioremediation on the chemical and nutritional composition of produce from crude oil-polluted sites. Unpublished doctoral dissertation. Cranfield University, Cranfield, United Kingdom.

26. Pinedo, J., Ibanez, R., Lijzen, J. and Irabien, A. (2013). Assessment of soil pollution based on total petroleum hydrocarbons and individual oil substances. Journal of Environmental Management, 130: 72-79. doi: 10.1016 / j.jenvman. 2013.08.048.

27. Radzevičius, A., Karklelienè, R., Viškelis, P., Bobinas, Č., Bobinaite, R. and Sakalauskiene, S. (2009). Tomato (Lycopersicon esculentum Mill.) fruit quality and physiological parameters at different ripening stages of Lithuanian cultivars. AgronRes, 7: 712 - 718.

28. Riahi, A. and Hdider, C. (2013). Bioactive compounds and antioxidant activity of organically grown tomato (Solanum lycopersicum L.) cultivars as affected by fertilization. Scientia Horticulturea-Amsterdam, 151: 90-96. doi : 10.1016 / j.scienta. 2012.12.009.

29. Ronen, G., Cohen, M., Zamir, D. and Hirschberg, J. (1999). Regulation of carotenoid biosynthesis during tomato fruit development: expression of the gene for lycopene epsilon-cyclase is down-regulated during ripening and is elevated in the mutant Delta. Plant Journal, 17(4): 341-351.

30. Sahlin, E., Savage, G. and Lister, C. (2004). Investigation of the antioxidant properties of tomatoes after processing. Journal of Food Composition and Analysis, 17(5): 635-647. doi: $10.1016 /$ j.jfca.2003.10.003.

31. Samara, C., Misaelides, P., Tsalev, D., Anousis, I. and Kouimtzis, T. (1992). Trace element distribution in vegetables grown in the industrial area of Thessaloniki/Greece, 1992. Annual Conference of Krikos Organization, Restoration and Protection of the Environment in the '90s.

32. Simonne, A., Simonne, E., Eitenmiller, R., Mills, H. and Cresman, C. (1997). Could the dumas method replace the Kjeldahl digestion for nitrogen and crude protein determinations in foods? Journal of the Science of Food and Agriculture, 73 (1): 39-45.

33. Singh, U.B., Sahu, A., Sahu, N., Singh, B.P., Singh, R., Singh, D.P., Jaiswal, R., Sarma, B., Singh, H. and Manna, M. (2013). Can endophytic Arthrobotrys oligospora modulate accumulation of defence related biomolecules and induced systemic resistance in tomato (Lycopersicon esculentum Mill.) against root knot disease caused by Meloidogyne incognita. Applied Soil Ecology, 63: 45-56. doi: 10.1016 / j.apsoil.2012.08.007.

34. Soil Remediation Circular (2009). Ministry of Housing, Spatial Planning and Environment Directorate-General for Environmental Protection.

35. Terry, L.A., Chope, G.A. and Bordonaba, J.G. (2007). Effect of water deficit irrigation and inoculation with Botrytis cinerea on strawberry (Fragaria $\mathrm{x}$ ananassa) fruit quality. Journal of Agriculture and Food Chemistry, 55(26): 10812-10819. doi: 10.1021/jf072101n. 
36. UNEP (2011). Environmental assessment of Ogoniland, 978-92-8073130-9, United Nations Environment Programme, Nairobi, Kenya.

37. Velterop, J.S. and Vos, F. (2001). A rapid and inexpensive microplate assay for the enzymatic determination of glucose, fructose, sucrose, L-malate and citrate in tomato (Lycopersicon esculentum) extracts and in orange juice. Phytochemical Analysis, 12: 299-304. doi : 10.1002 / pca.598.

38. Wang, Y. and Frei, M. (2011). Stressed food - the impact of abiotic environmental stresses on crop quality. Agriculture, Ecosystems \& EnvironmentJournal, 141 (3): 271-286. doi: 10.1016 / j.agee.2011.03.017.

39. Xu, J.G. and Johnson, R.L. (1995). Root growth, microbial activity and phosphatase activity in oil-contaminated, remediated and uncontaminated soils planted to barley and field pea. Plant and Soil, 173: 3-10.

\begin{tabular}{|ll|}
\hline Received & : Oct., 2018 \\
Revised & : Nov., 2018 \\
Published & : Dec., 2018 \\
\hline
\end{tabular}

